\title{
Export and Competitiveness of the Wine Sector Products of the Republic of Moldova in the Conditions of European Economic Integration
}

\author{
Elena Timofti, Romeo Cereteu \\ e.timofti@uasm.md \\ State Agrarian University of Moldova, Republic of Moldova
}

\begin{abstract}
The paper presents a research on the export and competitiveness of the products of the wine sector of the Republic of Moldova during 2011-2017. The dynamics of table grapes export with the partner countries have been analysed, as well as the trend of change and the forecast for 2022 have been determined. The authors investigated the structure of table grapes exports to the CIS countries, the European Union and other countries of the world. Based on the results, the most important aspects of the wine sector that need to be addressed have been outlined.
\end{abstract}

Key words: competitiveness, export, European integration, grape productivity, trend.

\section{Introduction}

Foreign trade is important for the Republic of Moldova. Being part of a complex system of economic, social and political relations, foreign trade is sensitive to the variation of a wide range of factors with direct and indirect impact.

Nowadays, Republic of Moldova needs a balanced policy aimed at overcoming the financial crisis, ensuring the competitiveness of Moldovan products including the products of the wine sector according to the trends and requirements on the world markets.

Market represents the mechanism that mediates between production and consumption, between the producer and the consumer. Allocation of resources, substantiation of the technologies and the ways of combining them, as well as testing of the quality of the decisions, the concordance of the supply with the social needs are made by the market through the price mechanism.

An essential feature of economic relations is represented by the competition mechanism. Through the competitive mechanism, those who are willing are favoured and the weak ones who do not have the necessary mobility to adapt to the new conditions in continuous change are eliminated.

Competition causes economic agents to orient themselves towards consumers, more precisely to their needs, trying to satisfy them in the best way, by offering products or services differentiated from those of other competitors.

The situation created on the domestic and world market of wine sector products generates a theoretical and practical interest in relation to the essence, factors and selection of the procedures for assessing the level of competitiveness. Competitiveness means the ability to compete, and competitive advantages form the advantages that offer the opportunity to compete. The competitiveness of wine products is determined by all the consumer and value characteristics that determine success both on the domestic and the foreign markets. A product is considered to be competitive if it tends to increase its quota on the market and maintains the relatively high price over a long period of time.

\section{Material and method}

The authors have used specialized literature, the legislative framework materials on the development of the wine sector, NBS data and the National Vine and Wine Office data in the research. The following methods and procedures have been applied during the research process: 
graphical method, table method, average andrelative value method, chronological series method and method for finding the trend of changing the indicators and determining the levels for the perspective through the extrapolation method.

\section{Results and discussions}

The wine sector is one of the most important areas of the national economy for the Republic of Moldova. The vineyard patrimony in all categories of households at 01.01.2017 amounted 135.3 thousand ha, which represents $5.4 \%$ of the total amount of the agricultural land surface. In the last years, the share of bearing fruit vineyards in the total amount of vineyards ranged between $91-95 \%$ or $128-130$ thousand ha. Wine varieties account for more than $80 \%$ and the table varieties -formore than $15 \%$ or about 20 thousand ha. The regulation and organization of the production activity in the wine sector is conducted in accordance with the state policy elaborated and promoted by the Ministry of Agriculture, Regional Development and Environment, as well as the legislative framework: the Law on Vine and Wine no. 57 of 10.03.2006; Government Decision No. 418 of 09.09.2009 on the approval of the Technical Regulation "Production, certification, control and realization of material for reproduction of grapes"; Moldovan standards (MS), etc.

The dynamic analysis of productivity per one hectare of bearing fruit vineyards in all categories of households showed an increase from 34.9 q / ha in 2010 to 46.9 q / ha in 2016.

The global grape harvest in most cases corresponded to the exigencies formulated in the activity programs. Figures 1 data show an increase of the global grape harvest in the Republic of Moldova from 594.8 thousand tons in 2011 to 674.7 thousand tons in 2017.

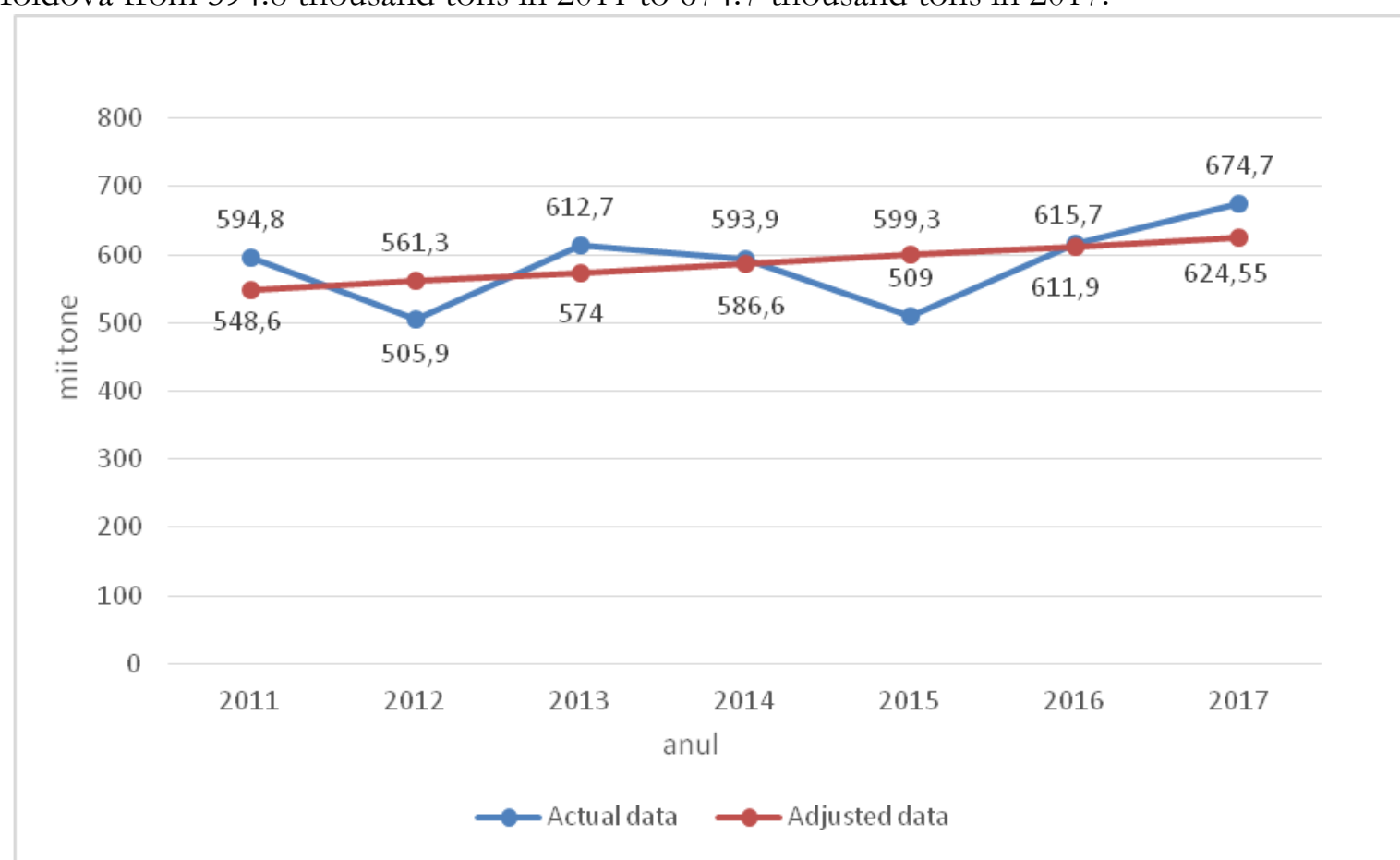

Figure 1. Dynamics and change trend of the global grape production in the Republic of Moldova, 2011-2017.

Source: Authors' calculations based on data from the Official Gazette of the Republic of Moldova no.366-376 (6761-6771) of September 18, 2018, p. 118.

Using the relationship of the geometric average (formula 1), the growth rate of the global grape harvest was calculated in the average of the years 2011-2017, which shows an increase of $15.8 \%$.

$$
\bar{R}_{c}=\sqrt[n-1]{\frac{N_{n}}{N_{1}}}=\sqrt[7-1]{\frac{674,7}{594,8}}=1,158 * 100 \%=115.8 \%(1)
$$


$\bar{R}_{c}$-average growth rate;

$N_{n}$ - last level;

$N_{1}$ - first level;

$\mathrm{n}$ - number of levels.

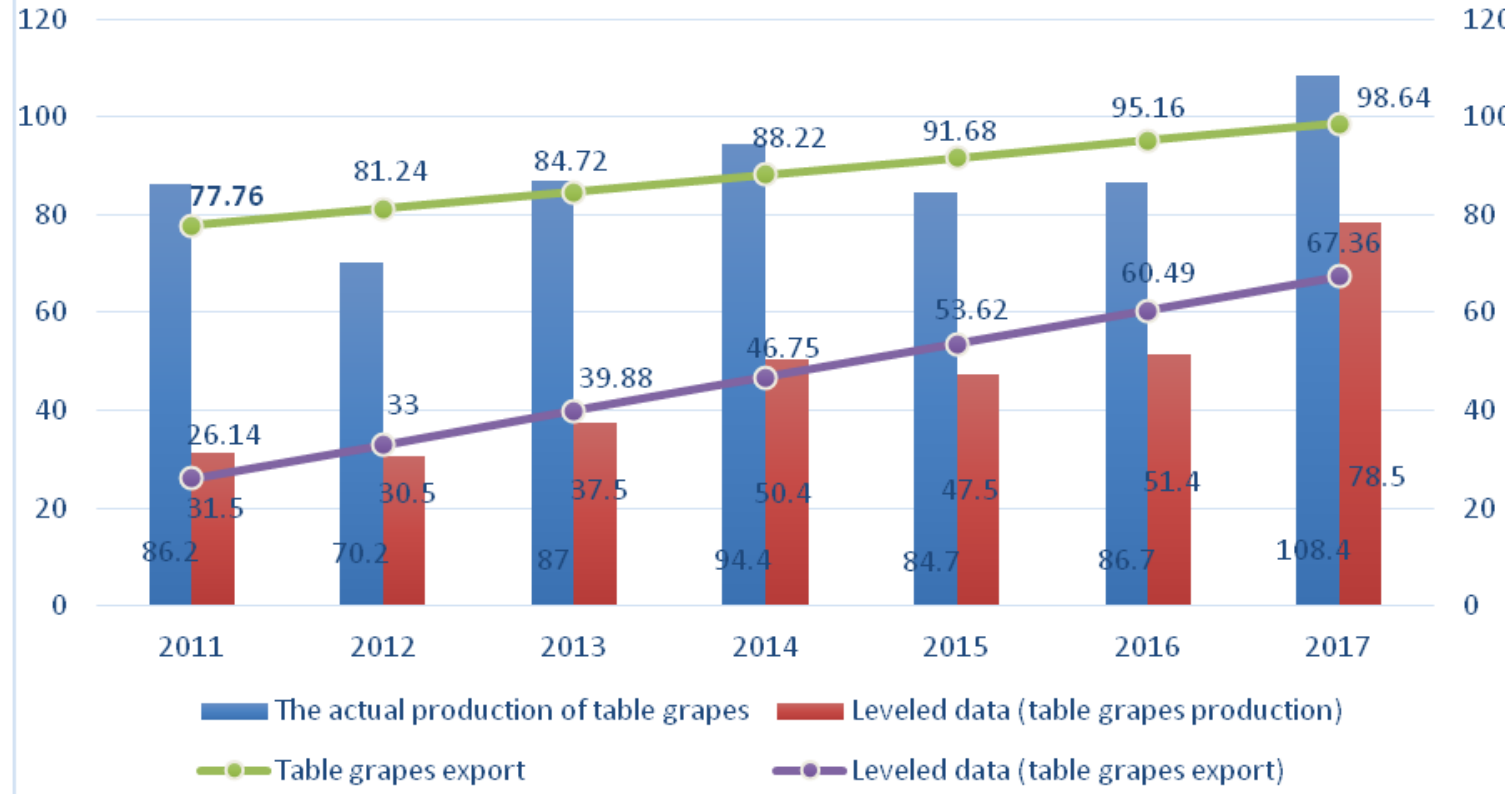

Figure 2. Dynamics of table grapes production and exports from the Republic of Moldova, 20112017, thousand tons

Source: Authors' calculations based on data from the Official Gazette of the Republic of Moldova no.366-376 (6761-6771) of September 18, 2018, p. 118.

Table grapes production $\bar{R}_{e}=\sqrt[6]{\frac{108.4}{86.2}}=\sqrt[6]{1.2575}=1.31 * 100 \%=131 \%$

Export volume of table grapes $\bar{R}_{\varepsilon}=\sqrt[6]{\frac{78.5}{31.5}}=\sqrt[6]{2.902}=2.9$ times.

Production of table grapes increased from 86.2 thousand tons in 2011 to 108.4 thousand tons in 2017 or by $31 \%$ on an annual average.

Exports of table grapes increased substantially from 31.5 thousand tons in 2011 to 78.5 thousand tons in 2017 or by 2.9 times more on annualaverage over the analysed period. Out of the total amount of table grape exports, the highest share belongs to the CIS countries: Belarus, Russia, Ukraine. From EU countries, a considerable volume of table grapes export is held by: Poland, Germany, Romania, Czech Republic. The other countries of the world imported lower quantities from the Republic of Moldova, but at a higher price per ton of grapes.

Through the linear method, the analytical adjustment was made on the basis of the first degree equation (relation 2) and the trend of change of the global production of grapes, including table grapes and the volume exported in the dynamics 2011-2017 (Table 1, 2 and Fig. 2) have been determined. 
Table 1. Data for trend determination and analytical adjustment realization through the linear method based on the 1st grade equation of global grape production in the Republic of Moldova, 2011-2017

\begin{tabular}{|c|c|c|c|c|c|}
\hline Year & $\begin{array}{c}\text { Global grape } \\
\text { production, } \\
\text { thousand } \\
\text { tons } \\
\mathbf{N}\end{array}$ & $\begin{array}{c}\text { Time } \\
\mathbf{t}\end{array}$ & $\boldsymbol{t}^{\mathbf{2}}$ & $\mathbf{N t}$ & $\begin{array}{c}\text { Equation of linear trend } \\
\text { and adjusted data } \\
\overline{\boldsymbol{N}}_{\boldsymbol{t}}=\boldsymbol{a}_{\mathbf{0}}+\boldsymbol{a}_{\mathbf{1}} \boldsymbol{t} \\
\overline{\mathbf{N}}_{\boldsymbol{t}}=\mathbf{5 9 6 . 6}+\mathbf{1 2 . 6 5} \boldsymbol{\mathbf { 5 }}\end{array}$ \\
\hline $\mathbf{2 0 1 1}$ & 594.8 & -3 & 9 & -1784.4 & 548.6 \\
\hline $\mathbf{2 0 1 2}$ & 505.9 & -2 & 4 & -1011.8 & 561.3 \\
\hline $\mathbf{2 0 1 3}$ & 612.7 & -1 & 1 & -612.7 & 574.0 \\
\hline $\mathbf{2 0 1 4}$ & 593.9 & 0 & 0 & 0 & 586.6 \\
\hline $\mathbf{2 0 1 5}$ & 509 & +1 & 1 & 509.9 & 599.3 \\
\hline $\mathbf{2 0 1 6}$ & 615.3 & +2 & 4 & 1230.6 & 611.9 \\
\hline $\mathbf{2 0 1 7}$ & 674.7 & +3 & 9 & 2024.1 & 624.55 \\
\hline Sum & $\sum \mathrm{N}=4106.3$ & $\sum t=0$ & $\sum t 2=28$ & $\sum \mathrm{Nt}=+354.2$ & $\sum \mathrm{Nt}=4106.3$ \\
\hline
\end{tabular}

Source: Calculated by the authors based on the data presented in Figure 1.

$\bar{N}_{t}=a_{0}+a_{1} t(2)$,

where:

$\bar{N}_{t}-$ adjusted data;

$a_{0}, a_{1}$-parameters of the equation;

$\mathrm{t}$ - time.

Equation in figures is as follows: $\bar{N}_{t}=596.6+12.65 t$ (global grape production) analogically, they are also calculated for:

table grapes production: $\bar{N}_{t_{\text {productia }}}=88.2+3.48 \cdot t$

table grapes export: $\bar{N}_{t_{\text {export }}}=46.75+6.87 \cdot t$

The obtained results show that during the researched period an increase of the volumes on an annual average was established in the following way:

- global grape production - by12.65 thousand tons;

- including the production of table grapes - by 3.48 thousand tons;

- export of table grape production - by 6.87 thousand tons.

Based on these results, the forecast for the year 2022 of the grape volumes was determined (Table 2).

Table 2. Trend of global grape production, including table grapes and those exported in 2011-

2017, and forecast for 2022 determined through linear adjustment

\begin{tabular}{|l|l|l|l|l|}
\hline \multicolumn{1}{|c|}{ Indicator } & \multicolumn{1}{|c|}{$\begin{array}{c}\text { Equation of } \\
\text { linear trend } \\
\overline{\boldsymbol{N}}_{\boldsymbol{t}}=\boldsymbol{a}_{\mathbf{0}}+\boldsymbol{a}_{\mathbf{1}} \boldsymbol{t}\end{array}$} & $\begin{array}{c}\text { Average level } \\
\text { during 2011-2017 }\end{array}$ & Forecast for 2022 & $\begin{array}{c}\text { Level of 2022 (+; } \\
\text {-) compared to } \\
\text { average from } \\
\text { 2011-2017 }\end{array}$ \\
\hline $\begin{array}{l}\text { Global grape } \\
\text { production }\end{array}$ & $\overline{\boldsymbol{N}}_{\boldsymbol{t}}=586.6+12.65 \mathrm{t}$ & 586,6 & 687.8 & +101.2 \\
\hline $\begin{array}{l}\text { Table grape } \\
\text { production }\end{array}$ & $\overline{\boldsymbol{N}}_{\boldsymbol{t}}=88.2+3.48 \mathrm{t}$ & 88,2 & 116.0 & +27.8 \\
\hline $\begin{array}{l}\text { Table grape } \\
\text { export }\end{array}$ & $\overline{\boldsymbol{N}}_{\boldsymbol{t}}=46.75+6.87 \mathrm{t}$ & 46,75 & 101.7 & +54.95 \\
\hline
\end{tabular}

Source: Calculated by the authors based on the data presented in Table 1 and Figure 2. 
The analysis of data from Table 2 shows that if the tendency of changes of the production and export of grapes as in the period of 2011-2017 will be maintained in the next years, and measures will be taken for the recovery of the wine sector, as well as the improvement of the quality and competitiveness of the grapes, then by 2022 the forecast will be the following:

- the global grape production will account for 687.8 thousand tons or by 101.2 thousand tons more than in 2011-2017;

- $\quad$ including the production of table grapes will account for 116.0 thousand tons, with 27.8 thousand tons increased;

- export of table grapes will reach 101.7 thousand tons with an increase of 54.95 thousand tons.

The increase in grape production indicators, including table grapes and those intended for export, was possible due to the result of the implementation of the system of economic, organizational and technological measures aimed at setting up vineyards for grapes as a commodity-production within the wine-growing area, the system of agro-technical measures applied at the elimination of the consequences of the deterioration of the vineyards by low temperatures, freezing, hail and other natural calamities, the establishment of vineyards with varieties of the species "Vitislabrusca" for the production of fresh grapes and the manufacture of foodstuffs.

Currently, the varieties register in the Republic of Moldova includes 27 table grape varieties. At the beginning, grape varieties such as White and black Coarna, Varatica, Moldova, Izabela, Kismis, Muscat de Hamburg etc. were cultivated. Due to the serious selection work at the NIVW, nowadays, they are gradually being replaced with new resistant varieties adapted to the local conditions: Early and Amber Muscat, White and Pink Apiren, White Frumoasa, Prezentabil, etc. In addition to fresh consumption, these grape varieties are also used for the preparation of various compotes, paste, jams, juices, etc. [Vacarciuc L., 2015]

\section{Conclusions}

1. Competitiveness of wine products is determined by the totality of consumption and value characteristics that determine success both on the domestic and on the external market.

2. Analysis shows that in the 2011-2017 dynamics, an increase of the global grape harvest by $15.8 \%$, and of the table grapes by $31.0 \%$ were registered, and their export increased on an annual average by 2.9 times.

3. The forecast calculated through the extrapolation method indicates that if the tendency to grow grape volumes is maintained for the future and measures to restore the wine sector, improve the quality and competitiveness of grapes are undertaken, then, by 2022, exports will reach 101.7 thousand tons with an increase of 54.95 thousand tons on an annual average.

4. Despite the growing trends achieved in recent years, the viticulture sector faces problems, which require solving in the following ways: replacement of vineyard plantations with new plantations with high yields and resistant to natural calamities, increase of subsidies and investments under the restructuring program of the sector, improving the quality and competitiveness of grapes according to the requirements of European Standards.

\section{References}

1. Monitorul Oficial al Republicii Moldova nr.366-376 (6761-6771), 28 septembrie 2018, pag.119.

2. Hotărârea Guvernului nr.418 din 09.07.2009 cu privire la aprobarea Reglementării tehnice „Producerea, certificarea, controlul și comercializ̧area materialului de inmulțire și săditor viticol "(Monitorul oficial, 2009, nr.112-114).

3. Legea viei și vinului nr.57 din 10.03.2006 (Monitorul Oficial, 2006, nr.75-78, art.314);

4. Standardele moldovenești (SM)-207:2010; „Material săditor viticol. Condiții tebnice", care stabilește cerinţe de calitate față de materialul săditor viticol. INSM. Chișinău, 2010; 
International Conference "Risk in Contemporary Economy" ISSN-L 2067-0532 ISSN online 2344-5386

$\mathrm{XX}^{\text {th }}$ Edition, 2019, Galati, Romania,

"Dunarea de Jos" University of Galati, Romania - Faculty of Economics and Business Administration

5. Standardele moldovenești (SM)-206:2010; „Material de inmulțire viticol. Condițiile tebnice”, care stabilește cerințe de calitate față de materialul de inmulțire viticol. INSM. Chișinau, 2011.

6. Vacarciuc L., Vinul: alte vremuri, alte dimensiuni; Compendiu oenologic- Chișinău: s.n,2015 (F.E.-P. „Tipografia centrală”)-608 p. ISBN 978-9975-53-577-9. 